cannot adequately assess, even when we recognise it, the full measure of this subtle influence. Quoting again from Emerson:

'Nor knowest thou what argument

Thy life to thy neighbor's creed has lent.'

We too are confused and uncertain; we too would like to taste the joy of life without feeling its pain. We too would like to live in a society where there is neither want nor hunger, neither hate nor prejudice, and where war has been outmoded. We too are searching for values to live by, for meanings in living. Like our patients, we are but human. Therein lies our greatest capacity to serve them.

\title{
TRIBUTES TO SIR LUDWIG GUTTMANN
}

ThE friendship between Dr. L. Guttmann, now Sir Ludwig, and myself goes back to the year 1927 when I, as a young student in neurology, was privileged to acquire the then most modern methods and ways of judging neurophysiological and neurological problems under his supervision. I shall never forget how Dr. Guttmann, chief physician of a very busy neurological and neurosurgical department in Breslau, found time, in spite of his extremely tight working schedule, to devote two full days in order to introduce me to the secrets of the interpretation and the diagnostic values of the new pneumo-encephalograms.

In I938 I was in the fortunate position of being instrumental in helping him to leave Nazi Germany almost after the eleventh hour. From I948 until today we have had many opportunities of meeting in Stoke Mandeville, abroad, and particularly in Israel, and of strengthening the ties of mutual friendship and understanding. I always admired his extraordinary approach to our war victims, among them the paraplegics whom he helped by appropriate advice and by taking adequate measures when necessary. His last visit to our country, on the occasion of the Stoke Mandeville Olympic Games, was an unforgettable highlight and experience due to his impact on the scientific gathering of the International Medical Society of Paraplegia in Jerusalem and also in Tel-Aviv.

Dr. Guttmann is a very great physician, having initiated, originally changed and scientifically executed treatment and rehabilitation of the spine-injured; and this consistently and efficiently. His influence in this field is overwhelming all over the world. Moreover, he is filled with a constructive optimism which carries with him so many of his colleagues and admirers. He is a great humanitarian and, last but not least, a real heart-to-heart human friend.

All the many Israelis who have known him, and all his circle of friends here, to which I have the privilege of belonging, wish to convey to him, on the occasion of his seventieth birthday, our best wishes for continuing his work and for many more years in his present good health.

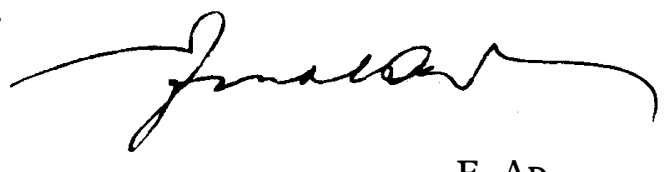

E. $A D_{\text {LER }}$ 
Si l'on considère les chirurgiens sous l'angle des services rendus à l'homme souffrant, Sir Ludwig Guttmann est certainement l'um de ceux à qui devrait aller la plus grande reconnaissance.

Quand on a connu, comme moi, ce qu'était le sort des traumatisés de la moelle entre I9I8 et I938, quand on a passé jour après jour devant l'un ou l'autre de ces jeunes blessés, cherchant sinon à donner un espoir tout au moins à dissimuler l'absence d'action thérapeutique, on apprécie l'immense progrès accompli.

Le mérite d'un chirurgien que guide non le désir de l'accomplissement technique, mais celui de trouver le moyen, quel qu'il soit, de rendre à um blessé infirme une dignité et un sens à sa vie, ce mérite provoque l'admiration et l'émotion.

La connaissance que j'ai faite de Ludwig Guttmann à Stoke Mandeville, l'émotion boulversante que j'ai ressentie en assistant aux Jeux Olympiques des paraplégiques, ont changé non seulement ma façon d'envisager un traitement, mais ont profondément influencé ma conception de la chirurgie en général, et ma façon de l'enseigner.

Tous les chirurgiens qu'il a aidés à vraiment comprendre le sens de leur mission, la prédominance de l'humain sur la technique, doivent lui apporter, comme je le fais aujourd'hui, à l'occasion de cet anniversaire, l'hommage de leur admiration et de leur affection.

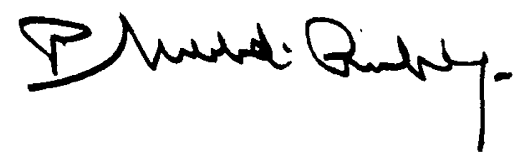

R. Merle D'Aubigne

IT was in Freiburg (Germany) about 40 years ago that I first saw a young, energetic colleague who was sent by his teacher, Foerster in Breslau, to operate on the daughter of a member of the medical faculty. Neither my young energetic conferee nor I had then any premonition that he would become Sir Ludwig Guttmann, a pioneer in the field of paraplegia who ranks with such men as Head, Riddoch and Munro.

Sir Ludwig came well prepared for his task. He had an outstanding background in medical and surgical neurology and the necessary attributes of the clinician, compassion, curiosity, patience, gift of observation, conscientiousness, devotion and rapport. He also brought with him a sportive spirit, the courage, the stamina and the quick reaction of the mountaineer and swordsman. All of these traits have contributed to-what I consider-the highlights of his achievements, i.e. autonomic dysreflexia, intermittent catheterisation and the ParaOlympics. He recognised the neuronal pattern of autonomic dysreflexia and thus opened ways of therapy when others merely observed the symptoms and signs without understanding the cause. He had the courage to break with orthodox urologic tradition by introducing intermittent catheterisation and thus prevented urinary infection in a great majority of his patients which, until then, was accepted as unavoidable by the profession. His enthusiasm created the Para-Olympics, recognising the driving force of competition which-once aroused-does not stop with the respective sport itself but spills over into everyday life, forming the nucleus 
for vocational, professional and industrial rehabilitation, combating self-consciousness and generating self-respect.

Sir Ludwig is a 'surgical conservative' guided by the experienced clinician's belief that nature is a great healer. This belief is reflected in the strictness of his indications and it has borne fruit as attested by the high percentage of his gainfully occupied patients, their high survival and low mortality rates.

$\mathrm{He}$ is a builder, who has not only organised the centre at Stoke Mandeville and provided so able a successor as Dr. J. J. Walsh, but he was instrumental as a consultant in the construction and development of centres in many countries of every continent. Even his retirement has not slowed down his untiring spirit with which he conducts his lecture tours.

And last but not least, had it not been for Sir Ludwig, neither the International Medical Society of Paraplegia nor its official fournal would have existed which now conveys our tribute to him.

My staff and I salute you, Sir Ludwig, on your seventieth birthday and we wish you good health and strength for the continuing success of your great humanitarian mission.

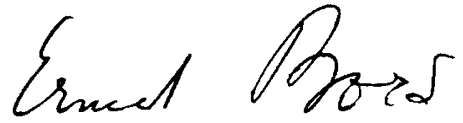

ERNEST BORS

ON 3 July I899, when Sir Ludwig Guttmann was born, a fracture to the spine with associated damage to the spinal cord was regarded as an exceedingly serious condition, and a certain road to the hereafter. One can remember how, only 30 years ago, people shook their heads and sighed knowingly when they heard of someone who had sustained a fractured spine, implying as they did that death was not far off.

In I939, Sir Ludwig came to England bringing with him considerable skills in neurology and neuro-surgery and became a Research Fellow in the University of Oxford. After a few years, the National Spinal Injuries Centre was set up at Stoke Mandeville in I944, and in Sir Ludwig's own words, 'This unit has revolutionised a subject which, in the whole long history of medicine, was one of the most depressing and neglected'.

I was privileged to meet Sir Ludwig Guttmann for the first time in I940, in Oxford, where he was carrying out research and investigation upon the peripheral nerves at the Wingfield Morris Hospital.

Today, the outlook for a paraplegic is completely different. He is expected to carry on with his pre-accident work or at least be re-educated to perform a useful job and take a useful place within the community. Many patients suffering from this disability occupy very important positions in the world today and are able to maintain themselves in competition with their hale and hearty fellows.

This has not come about automatically but has become possible by the devoted and dedicated work of people who have worked hard to solve the problems of these severely handicapped people. The leader of this group in Great Britain has been Sir Ludwig Guttmann, and he has accomplished many things for paraplegics.

One of the many important contributions that Sir Ludwig has made has been 
the formation of the International Medical Society of Paraplegia, of which he is President, and the associated journal which the Society publishes named Paraplegia.

The two contributions have led to the spread of the knowledge of treatment of paraplegics to the farthest corners of the world. These patients are now treated by people who have learned from the fournal, or from meeting at the Society, or from visiting Stoke Mandeville.

The Stoke Mandeville Games were started in 1948, and this was a very important introduction of competition among paraplegics. This has led to the ParaOlympic Games and the Para-Commonwealth Games.

Some years ago the American Paraplegic basket-ball team came to Hong Kong to play the local team. The local team was a very scratch team as we have only just been able to institute proper care and diversions recently for paraplegics. It was amusing to see the big, husky Americans playing the very small Chinese. The game would have been one-sided except that one of the most adept of the Cantonese had a Hong Kong-made wheelchair; this wheelchair, like so many things Chinese, was propulsed backwards, and this one paraplegic who had a chair which went a different way really confounded the American defence. It was interesting to see how quickly this was appreciated by the team and how much less one-sided the game was accordingly.

The greatest contribution, and perhaps the greatest characteristic of all great men is the fact that they have trained others to carry on the good work, and this Sir Ludwig has done in all parts of the world.

In September 1968, Sir Ludwig came to Hong Kong as the chief representative from the United Kingdom to attend the Fourth Pan-Pacific Rehabilitation Conference organised by the International Society for the Rehabilitation of the Disabled in conjunction with the Hong Kong Joint Council for the Physically and Mentally Disabled. This was attended by over Iooo people and was the first and biggest of its kind ever held in Hong Kong.

He was the first principal speaker of the plenary sessions; he took part in the Scientific Sectional Meetings; he even took an active part in the small group discussions. His dynamic personality was a great inspiration to everyone, and his enthusiasm was not at all dampened by the long journey to Hong Kong or the demanding programme of the conference. Sir Ludwig's devotion and sincerity have left a deep and lasting impression upon all who are working for their less fortunate fellow-men.

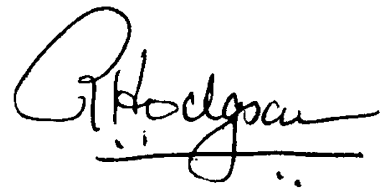

A. R. HoDGSON

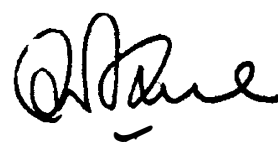

HARRY FANG 
IT is never easy to write objectively of a contemporary during his lifetime. Objectivity is difficult to achieve in any field of human endeavour and nowhere more so than when assessing a human being with all the variables which enter into human behaviour in a complex society.

Sir Ludwig has been well known to us since the end of World War II when his efforts on behalf of paraplegics became known, first through the experience of those who were in England during World War II and shortly thereafter to a wider audience through his writing. Although he spoke out strongly on behalf of exemplary care in his writings, and there was no uncertainty as to his views on the surgical and nursing care of these patients, his clinical contribution (which will probably prove to be most significant) has been the introduction of the practice of intermittent catheterisation from the time of injury with consequent preservation of sterility of the bladder urine. One rather feels, however, that it will not be for his writings that he will be hailed so much as for his dynamic determination to establish the best paraplegic programme anywhere in the world. To achieve this, he directed his energy and enthusiasm, together with nolittle administrative skill, toward the goal of creating adequate facilities in war-time England and to develop these further under the National Health Programme when hospital building did not keep pace with the community needs. In addition to operating a very large treatment programme, he also disseminated the fruits of his experience through personal contact with the many visitors to Stoke Mandeville and through his personal travel to faraway places. He sowed the seeds of rehabilitation for the paraplegics in disparate societies around the globe. We feel, therefore, that it will be in the broader context of his achievement, that is his contribution to paraplegia generally, that he will be hailed as a pioneer and leader in this field. To ensure perpetuation and growth of this work he was foresighted enough to have led in the formation of the International Medical Society of Paraplegia. The establishing of the official journal Paraplegia has given this Society a voice which is heard around the world, strengthening and advancing the cause of each individual paraplegic and all who are profoundly disabled.

Sir Ludwig himself could well esteem the founding of the International Sports competitions for paraplegics as his most satisfying achievement. From personal observation we know that he derived much happiness and contentment from seeing many seriously disabled persons arrive at Stoke Mandeville from all parts of the globe for the Annual Games. Despite their disabilities, many of them had every appearance of good health and were energetically enthusiastic about the competition and as a by-product of this type of therapy a significant number were restored to useful living.

To us, his colleagues in peace and war, it seems that Sir Ludwig's devotion of his scientific imagination with singleness of purpose, backed by his courageous endurance to the welfare of paraplegics, has resulted in a noble achievement.

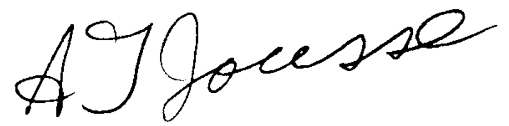

A. I. Jousse

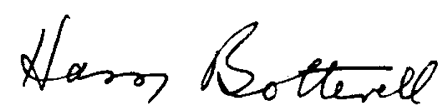

E. HARry BotTERELl 
ONE is not of ten granted the opportunity to watch one's own life work blossom into even greater growth through the efforts of a friend who has demonstrated an interest in it equal to your own.

It is for this reason that I consider myself especially favoured by having been asked to have a share in marking the seventieth birthday of that master neurological surgeon, investigator and promoter of the public good that goes by the name of Sir Ludwig Guttmann, the subject of this tribute.

When World War II broke out, this man escaped with his family from Germany and came with them to England in response to an invitation to take charge there of the care of those British troops that, in particular, had sustained wounds and injuries to their spinal cords.

At this time the organised care of this class of war wounded had recently been seriously commenced in only the United States, and particularly in certain United States Veterans Hospitals which had been built, staffed and organised by the Veterans Administration of that country. As an ancillary part of this, selected United States Army Hospitals, notably in Framingham, Massachusetts, New York, Chicago, Memphis, Los Angeles and other suitable locations were included as institutions suitable for the treatment of these patients and for forming paraplegic services at the start and then later expanding them to 'paraplegic hospitals'. The earliest and the leading such hospital service was developed at the Cushing General Hospital under my direction and later continued there for the use of the Veterans Administration and for the veteran civilian injured of this group at my clinic at the Boston City Hospital in Boston.

Sir Ludwig transplanted the best of these activities to England for his own use, having been already well trained for this activity in Germany by his preceptor, Professor Foerster, in that country.

To an acute observer like Sir Ludwig, it was soon apparent that the great need in this field was, first, a method of getting the wounded or injured patient with damage to his spinal cord to a trained doctor who worked in a properly equipped and staffed hospital. Secondly, basic, key information, not of the class of technical surgical knowledge of which he already possessed more than an adequate amount, backed in addition by imagination and an analytical mind necessitated transfer there as soon as possible by the quickest method was just as essential and was perhaps the more important of these two basic requirements.

To meet these needs, he has constructed a centre for the care of spinal injuries at Stoke Mandeville and put in use a helicopter ambulance service as quickly as possible as the result. As an inevitable further result, Great Britain became the first self-contained area to be properly organised to care for these patients. The foundation for this had been previously built originally in the United States and Canada.

As a part of this broad therapy, Sir Ludwig also made use of the passion for competitive athletics characteristic of young adults and especially so in those with an Anglo-Saxon heritage. To accomplish this he organised the present Paraplegic Olympiads. This brought him increased recognition, praise and respect.

It also brought pressure to bear on him to use his knowledge and organisational talents on the problem of spinal cord injuries on the European continent, Australia and South Africa, whose patients notably from France, Spain and Turkey as well as from the larger cities in the two other continents, if they could afford it, had had to be sent up to this time to the North American continent and frequently 
to Boston for treatment and rehabilitation, a trip which added greatly to the risk of increased future invalidism.

His greatest monument, however, aside from that lasting one built by himself out of patient care, will be this fournal and the organisation which supports it-The International Society of Paraplegia. This represents a great humanitarian contribution well deserving of the honour his Queen has bestowed on him, one which includes a unique and rare universal respect.

As he continues to adorn this world with his presence, is kept in continuing health by Lady Guttmann's care, and is forced to stay young by his children's stimulus and machinations, he will come to learn, as I have, that retirement is a wonderful time to begin to know and appreciate the mass of friends who started as his patients, the throng of students who are now his co-workers and the indispensible helpers and burden-carriers disguised as nurses, technicians, managers, cooks and 'carpenters' who have been proud to have been a part of this remarkable man's life.

May you continue to live to exercise your fertile imagination and unique skill, to bask in the irreplaceable glow of your happy family life, is my sincere wish for my long-time and highly valued friend.

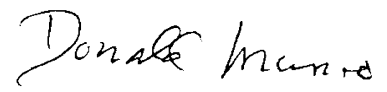

Donald MunRo

THE change in outlook of the paraplegic patient between the first and the second world wars is little short of miraculous, and its chief architect has been Sir Ludwig Guttmann. In World War I the treatment of the bladder was a surgical failure; Sir John Thomson-Walker (Br. F. Urol., 9, 217, I937) reported an 80 per cent. mortality from urinary sepsis. In World War II the early cases of spinal injury were again surgical failures.

Early in 1942 I was instructed through Dr. George Riddoch by the Nerve Injuries Committee of the M.R.C. to visit the four centres in which paraplegic patients were segregated. They were mainly members of the armed forces; civilian air-raid victims came later. The majority had received their initial treatment overseas and had waited many weeks before admission to the centre. By this time the effects of urinary sepsis were only too apparent; nearly all of them had cystitis, often encrusted, and many had renal infection with hydronephrosis or calculi. They were toxaemic, and pressure sores were prevalent especially when plaster casts had been used or urinary leakage had occurred. Infection was worse after an indwelling catheter than after intermittent catheterisation; when suprapubic cystotomy had been performed the opening was generally so low and so large that urine escaped around the tube. The incidence of bed sores and toxaemia ran pari passu with severe urinary infection.

The staff in the centres had a depressing task; they were faced by seriously ill patients who were beginning to lose hope. It was another year before the establishment of the National Spinal Injuries Centre at Stoke Mandeville. Dr. Ludwig Guttmann had already given a clinical review of spinal injuries and in I944 he was appointed the first Director of the Centre. He was an experienced neurologist, 
trained in Freiburg and formerly Lecturer in Neurology in the University of Breslau. He was confronted at Stoke Mandeville with the same type of patient, admitted late, already wasted and toxaemic and it took courage on the part of both staff and patients to foresee any real hope for the future. But Guttmann had both courage and determination. His policy was to treat the patient, not the injury; stones could be removed by the urologist, sores covered by the plastic surgeon and deformities treated by the orthopaedic surgeon, but he was the moving force behind the whole treatment and the patients themselves recognised it. He insisted on the development of the unparalysed muscles, using games like wheelchair polo and netball to achieve it; these helped materially to maintain morale. Workshops were established, competitions devised and a renewed hope and will to live a useful life became evident. A magazine, The Cord, was published in 1947 under the Chairmanship of Padre Bull, one whose influence amongst his fellow-paraplegics was a highlight in the Centre. It is pleasing to know that he is still alive and active in 1969. The first number contained a promise of an article by Dr. Guttmann and a note that 'he is all for getting fellows on their feet-literally-and out once more into the world'. The promised article, which appeared in the second number, was characteristically on the psychological aspects of readjustment to a new life; one on the physical aspects came later.

The technical details of treatment were revised to conform with the overriding aim of rehabilitation; plaster beds were abolished and physiotherapy started; the indwelling catheter was abandoned in favour of intermittent catheterisation carried out with full aseptic and antiseptic precautions. Patients were still received late and many already had renal complications; stones had to be removed; nephrectomy was not to be thought of even in a frank pyonephrosis. Guttmann's ideas were respected and although we had some difference of opinion the policy of conservation was willingly followed. The small highly suprapubic catheter did not receive a full trial largely because most patients came late; it is encouraging to find it advocated in 1968 by E. W. Kyle (Int. F. Paraplegia, 6, I, I968) and I still think it is the best method of initial treatment.

Guttmann founded the International Medical Society of Paraplegia in I96I; its excellent journal Paraplegia appeared in I963. The Stoke Mandeville Games, started in 1948, have become an International Olympiad for paraplegics. Spinal Injury Centres have become established throughout the world, many staffed by trainees from Stoke Mandeville which has become the mecca of all who deal with the specialty. It is a far cry from the early fight for facilities, staff and equipment; the success achieved is a tribute to the persistence, determination and faith of Sir Ludwig. The many honours which have been showered upon him bear witness to the esteem and respect which he enjoys throughout the world. We wish him a happy seventieth birthday and a long life in which to enjoy his retirement but we are sure he will continue to serve the cause of paraplegics.

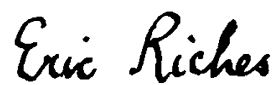

ERIC RICHES

WITH the rapid passage of years memories fade for us all, but one memory which will stand out for me as an Australian was my first visit in the winter of I95I to a ward round conducted by Sir Ludwig at Stoke Mandeville Hospital. Despite 
snow, ice and sleet, I set out early one January morning to travel to Stoke Mandeville along roads I had never seen before to meet this dynamic personality, who had so revolutionised the management of paraplegia.

After many vicissitudes with ice and snow, I eventually reached Stoke Mandeville to be welcomed and immediately made to feel at home. Such a day is rather symbolic of an era in the management of paraplegia, when prior to the work done by Dr. Guttmann there was much coldness in the whole field. With the advent of Stoke Mandeville and other world centres at the time of World War II the climate changed immediately.

Having visited Stoke Mandeville a number of times during my three-year sojourn in England, it was not surprising that on returning to orthopaedic practice in Australia I found my task lay in the field of paraplegia. In 1954 the first Paraplegic Unit in Australia was established by the Board of Management of Royal Perth Hospital. In 1957, through the generosity of the Nuffield Foundation, Dr. Guttmann paid a visit to Australia, visiting each capital city to further the work among paraplegics. In many places only apathy and disinterest met him with the usual vitriolic result with which we all became so well acquainted.

Mr. Eric Kyle, Senior Visiting Urologist, recalls that during the visit to Western Australia Dr. Guttmann discussed the future care of paraplegia in Western Australia with a number of members of the honorary medical staff. He was surprised to learn that the development of the Paraplegic Unit at the Royal Perth Hospital had been undertaken under the honorary system of public hospitals in Australia, and he made the following remarks: 'You are very fortunate in this regard, but I regret to say that you will not always be so fortunate'. Time has passed and these remarks have come true. I remember how surprised he was to find that in the period of a working week, the Paraplegic Unit was directed and run by honorary medical staff giving up as much as four to five sessions per week to look after paraplegic cases.

Subsequent to his visit to Western Australia, the first Australian Paraplegic Team went to Great Britain in I957. Two days after the Games were held I had the opportunity of again visiting Stoke Mandeville and spending nearly a week with Dr. Guttmann and his staff. One could only be more and more impressed with the personality of the man who had made such a difference to the lives of thousands of people, not only in Great Britain but even at that stage in many other parts of the world. It showed that the impossible was possible in medicine and he had broken down a frontier not crossed since the days of Hippocrates.

The year I962 saw Sir Ludwig Guttmann back in Australia for the First Commonwealth Paraplegic Games and I well remember his obvious delight at landing in Perth, 'the City of Sunshine', in teeming rain, and his twinkle of amusement as he spoke to Press men at Perth Airport, discussing with them the international value of such sporting activities.

By this time he was well known for his straight-forward, dynamic personality and his straight-forward thinking in regard to paraplegia. This hit many complacent Australians badly, some of them never to recover, particularly when he talked about the problems of bladder infection. He stressed his now well-known management of the bladder by intermittent catheterisation and avoiding distension of the bladder which may cause such slow recovery in the automatic function of this important organ. At International Society meetings, which I have had the good fortune to attend over the last Io to I5 years, he has always shown his complete 
mastery of the subject which one has come to regard as being peculiarly his own. In Australia he will always be remembered as somebody who sheeted home some very unpleasant but very necessary and accurate truths. For this he was not well liked, but those who knew him best regarded him as a refreshing wind blowing among the reeds and bringing a welcome change at long last.

Perhaps his greatest work, and one which will be remembered for many generations to come, has been the way he has stimulated the growth of paraplegic services all over the world, urging that Man be given the right to live under all circumstances, and thus showing Medicine to have catholicity throughout the world under all faiths and all governments. The recent International Stoke Mandeville Games meeting in Tel-Aviv showed that this was perhaps the greatest piece of work that this remarkable man has undertaken over the last 25 years of a very distinguished career both as a neurosurgeon and now as a world specialist in the field of spinal paralysis.

No words of mine can show adequate appreciation to the man and his work, but I may quote from the volume of Sacred Law and say: 'By their deeds ye shall know them'. By the words, actions and deeds undertaken by Sir Ludwig Guttmann his name will forever be remembered by those working and living in this field, both by patient and doctor alike.

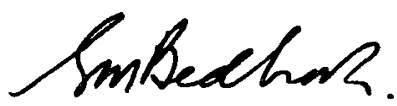

GEORGE M. BEDBROOK

SIR LUDWIG GUTTMANN visited Argentina in I964 and presided over the National Games for the Disabled. On this occasion somebody was complaining for having lost in one of the events. Sir Ludwig answered: 'In these competitions nobody loses, everybody wins from the mere fact of having competed'.

Thus he insisted that we ought to make the great effort of extending the movement to the rest of South America. 'You must teach them', he said.

Following this suggestion, in 1965, the National Rehabilitation Centre of Buenos Aires organised the first of three courses on 'Technical Education in Sports for Disabled, according to the rules established in Stoke Mandeville, England'; several Latin-American countries were represented, and also nearly all of our provinces.

Before leaving Argentina, the famous painter Quinquela Martin honoured Sir Ludwig Guttmann with the 'Orden del Tornillo' (screw Order), for being an outstanding personality. While we were eating the multicoloured spaghetti that is served as a part of the ceremony, Sir Ludwig said to me: 'This is the most comical decoration I have ever seen in my life, but I truly wonder if I deserve it . . .'

In 1968 when I was in Israel, somebody referred to that country saying: 'You have to be very unrealistic not to believe in miracles'; to which Sir Ludwig Guttmann answered: 'Especially if you have worked so hard for them to appear'. The same quotation can be used for his humanitarian and scientific work.

While writing these lines and trying to look backwards with concentration, I realise now how much a man can do following his example and his contagious will 
of creation. He originated ideas that have no frontiers, and produced far-reaching effects that cannot be foreseen.

Even if some absent-minded people might forget Sir Ludwig Guttmann's work it will go on ahead. Humanity is inspired by his spirit.

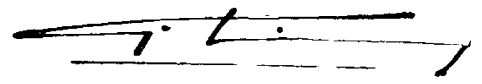

Jose B. Cibeira

DURING a Rehabilitation Course in Spain I heard about the treatment of the paraplegics by Dr. Guttmann at Stoke Mandeville Hospital, and during a two-months visit to England it was obvious that I should pay a visit to Stoke Mandeville Hospital and see the organisation of the famous Spinal Unit.

My knowledge about paraplegia was almost nil and I was quite prepared to fill this gap in two weeks! This was in November I964.

The depression I felt when I saw for the first time the gloomy black barracks of the Hospital was quickly dissipated when I met Dr. Guttmann himself, being much impressed by his overwhelming personality and by the devotion that his staff professed to him. As happens to every visitor, Dr. Guttmann was very kind and I soon appreciated the wonderful organisation of the Hospital and the splendid results obtained. Thus curiosity changed into a growing interest in mastering the principles that could give a new life and a new hope to the paraplegic. Needless to say, when he offered me a post to work with him I changed my plans completely and instead of a two-weeks visit I spent almost three years there.

To work with Sir Ludwig was always interesting and encouraging and he was kind teaching us neurology, and what is more important in giving us confidence in our will-power. It is surprising how much a man can achieve with a strong will even with poor means, but one needs really to discover this secret force otherwise it is lost. To have confidence in his will-power and put all his means to his task is the greatest achievement of a man for success in every walk of life.

Imparting to the patient the idea that he must retain what abilities remain and to forget what has been lost, may not be very easy in the early stages of a spinal cord lesion, but it is essential for his rehabilitation. Very soon the patient himself realises the achievements of similar patients and begins to have confidence in himself.

According to Sir Ludwig Guttmann every patient must be willing from the very beginning to live as normal a life as possible. There are, of course, obstacles to the wheelchair, but they can be overcome in most instances if the patient tries seriously to fight against his fate. Furthermore, sports apart from strengthening the muscles, give patients a new and strong confidence in themselves.

The basic principles and teachniques of Sir Ludwig in the treatment of the paraplegic patient are strictly physiological, based on common sense and simplicity. Not a single detail is overlooked, however small it may be, everything has been taken into account and nothing left to chance. It is the result of long hours of study, and the working capacity of Sir Ludwig is very great. The confidence that he inspires in his patients gives them the strength to follow scrupulously his advice without discouragement, in spite of the difficulties that exist in this disheartening condition. 
With his staff Sir Ludwig has been always strict and would not tolerate laziness or procrastination as he has never been given to them; many times he made jokes of our typical Spanish motto 'mañana', but we all loved, admired and respected him and were always ready to stand by him. We could in turn find him always ready to help us and to give us his valuable advice.

When I had to leave Stoke Mandeville I felt very sad because it was already part of my life and soul, and I still consider these three years as the most fruitf ul of my life.

A few months after leaving Stoke Mandeville I was called to run a Spinal Unit in Sevilla and I have tried to apply scrupulously every principle I learned from Sir Ludwig and still keep in close contact with him, asking for his advice. I only hope to do for my patients as much as he has taught me to do.

There is very much to say about Sir Ludwig Guttmann and Stoke Mandeville Hospital, but no words can express the reality. It is much better to go there and see the Man and his Work.

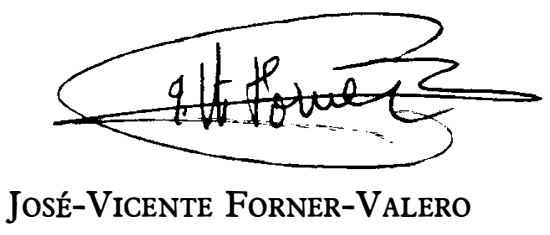

IRELAND owes much to Sir Ludwig and to the team of workers whom he brought together. I worked as a junior medical officer at Stoke Mandeville from 1947 to I948 and well remember the combination of Dr. Guttmann, the doctor, with his patient, the medical scientist dedicated to research, and the pugnacious and determined fighter for his unit.

His enthusiasm for the cause of the handicapped was not limited to his own unit. He welcomed members of the Irish National Rehabilitation Board to Stoke Mandeville and later came to Dublin to advise our Minister and his officials. Asking his opinion about the present centre his comment was 'get started'. He arranged for a medical and nursing team to be trained for us and gave us a flying start.

Some patients from Ireland had had the good fortune to be treated at Stoke Mandeville and returned motivated to help others in Ireland. One, Leo Close, was the first paraplegic to be ordained a priest with special permission from Pope John. He with his friends founded the Irish Wheelchair Association to improve the social work and sports opportunities. They have welcomed the International Games pioneered by Sir Ludwig and the international fellowship that these have brought.

Trinity College, Dublin, has fittingly conferred the honorary degree of Doctor of Laws on him this year. His comment was that he is now qualified to keep the peace between us. May he long continue to do so.

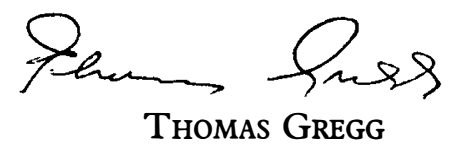


IN the present discussion on re-modelling of the German Universities the work of the professors is sometimes criticised. Examples of defects due to the old 'System' abound but it is not clear whether the mode of selection or the many years of frustration and 'adaptation' are not to blame. From the collected evidence it is concluded that in Germany the young lecturer has to submit to the demands of his immediate seniors in a servile manner.

As soon, however, as he himself achieves the pinnacle of almost unlimited power over men and means, he rapidly forgets his own painful experience and becomes another authoritarian member.

Many remedies have been suggested. Work-and career-structure are to be improved, promotion is to be made easier and efficiency increased.

In this conflict of opposing views the example of personalities is of considerable value, those who in spite of extraordinary difficulties and ample opposition were able to achieve a position in which they could turn their vision into reality and exert far-reaching influence.

Sir Ludwig Guttmann did not have the opportunity of climbing smoothly from rung to rung on the academic ladder. Political events in Germany forced him to leave his old chief Otfried Förster, and to try (as Director of the Jewish Hospital in Breslau) to secure for his patients the best treatment possible under the circumstances. This demanded courage and energy of a high order and it was this time of hardship which trained him in a way very different from that needed in an ordinary academic department for the position of authority which has earned him gratitude and recognition all over the world.

Since the end of World War II he has had a decisive influence on developments in German University Departments. Over the years many professors of orthopaedic surgery, neurology and neurosurgery have visited Stoke Mandeville and have acknowledged the advances in treatment which had been developed there. In the last few years they have done their best to improve the facilities for the rehabilitation of paraplegics within their own spheres of influence.

Besides spreading the message of his experience and methods with the help of his pupils, young and old, to Universities and special Centres, Sir Ludwig has acted as Adviser to Government Departments and Insurance Organisations, thereby greatly assisting progress. In spite of this unconventional double approach the German Universities were happy to benefit from his catalytic activity. They showed their gratitude and recognition by appointing him Professor Emeritus of the University of Cologne, which acts as representative of the former University of Breslau.

For many of our own and progressive academics this may appear belated recognition restricted, after all, to one individual. But here is a symbol. Here lies encouragement for adventurous, energetic clinical and scientific workers. They will not give in. They will overcome individual obstacles and achieve for tomorrow's society the freedom for scientific progress within and without the Universities, even in spite of traditional conservative elements.

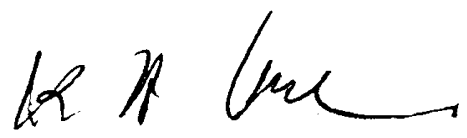

K.-A. JoCHHEIM 
I AM honoured to add my tribute to Sir Ludwig on the occasion of his seventieth birthday.

As one of the first neurologists to be sent from Germany in 1956 to the National Spinal Injuries Centre, Stoke Mandeville Hospital, I can testify to the impact of his work on his patients, his co-workers, his staff and his colleagues in Britain and far beyond its borders.

Until we worked in his wards, watched every step of diagnostic, preventative and therapeutic procedure, followed him on his rounds and appreciated the continuous stimulus of his drive and attention to every detail, we had not believed what we had heard about the radical change of outlook he offered these severely disabled people.

Ever since then I have tried to help to introduce his methods into our centre in Bayreuth. Like my German colleagues I have been able to show that these methods are of the greatest value to our patients and have convinced the authorities that here too we must try to improve the organisation and equipment of special centres for para- and tetraplegics, whose number is steadily rising. I was deeply impressed by the combination of his wide knowledge and insight into the problems of these patients and with his powers of action and organisation. He overcame obstacle after obstacle in the development of the modern concept of rehabilitation and reintegration of his patients into society.

Then, his work was a revelation to us. Today it remains the guiding star for all working in this field.

As one of many, I wish Sir Ludwig continued good health and years of fruitful work for all those who owe their survival and the very quality of their lives to his unceasing efforts on their behalf.

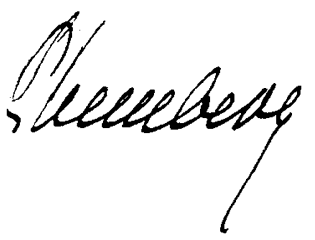

K. L. LEMBERG

I FIRST met Sir Ludwig Guttmann many years ago, just after the war. Sir Zachary Cope introduced him to me, not in person but only in the book edited by Sir Zachary (Medical History of the Second World War: Surgery. London: H.M.S.O., I953). I discovered something really new, revolutionary, positive and definitely important about paraplegia. The author was Ludwig Guttmann.

About this time I was planning to build a Spinal Centre for people with industrial injuries, in Italy, and I remember repeatedly reading this paper and realising that its author was a giant and somebody with extraordinary powers.

I had the honour to meet him personally a few years later in the summer of I956, and I must admit my first emotional idea borne in my mind by his appearance was disappointment that he was not as gigantic as I had anticipated. Little time elapsed, after a better acquaintance, before I realised that he was larger than I had imagined. 
I learned many things from Sir Ludwig about paraplegia and many valuable suggestions for my Centre in Italy, and I received vast experience in sport for the disabled and many other gif ts; and therefore I was very excited when, in I960, I was able to give something in return.

In that year there was great excitement in Rome on account of the Olympic Games, and Sir Ludwig gave me the responsibility of organising the Stoke Mandeville Games in Rome with the purpose of widening and extending the scope of these Games for the disabled.

We in Rome all did our best and the Games were held in the same famous stadiums and sports fields that were used for the Olympic Games. The First Lady of Italy, the wife of the President of the Italian Republic, was high Patroness of the Games, and His Holiness Pope Giovanni XXIII received all the participants of the Games in the Vatican. Moreover, the press, television and public interest gave a big boost to this sports' movement. The Stoke Mandeville Games, one of the masterpiece creations of Sir Ludwig, began to spread its wings further.

Thank you, Sir Ludwig, for the Stoke Mandeville Games, thank you for your knowledge in paraplegia, thank you for the journal Paraplegia, thank you for all the other things you have created in the field of paraplegia, but above all thank you for the many years more that in future you will steer, with your young and wise hands, the ship of paraplegia.

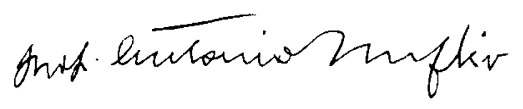

Antonio Maglio

WHEN in I95I I had the opportunity to enter, for the first time, the Stoke Mandeville 'Temple', one of my first pleasures was to accompany you on your rounds. Immediately I was struck by your radiant optimism and your authority, which although firm was cheerful. Amidst your clinical examinations and prescriptions, a joke, a humorous 'Jolly-good' left behind the trace which gave back a taste of everyday life to all your patients. But there were also questions which everyone feared, the terror of a fine if a pressure sore appeared. Your replies were sometimes surprising, as when I asked you, one day, if you taught your paraplegics how to fall, and you replied, 'It is not worth it, they can fall alone!'

There are plenty of reasons for the many who admire you to do so. Your capacity for great ideas is equalled only by your care for detail, your speed of judgment competes with its depth, and you always seemed to ignore the opinion of Goethe, which was 'to act according to one's thought is the most difficult thing in existence'.

You have shown the paraplegics how, and to what extent, they could use their remaining faculties, and I would be very surprised if there was one rehabilitated paraplegic who did not know your name. You have demonstrated to the physician -at a time when specialisation is placing personal contact with the patient at a greater risk-what was, in fact, his real responsibility. You have laid as much importance on the social aspect as on intermittent catheterisation, and this is, by no means, small. 
Looking back at your work, I recall this verse by an athetosic poet:

'Je dois infiniment vaincre des impossibles'.

You also have of ten defeated impossibilities, and many of your paraplegics have, naturally, copied you.

To the Clinical Physician, the Neuro-Physiologist, the Pioneer, the Pilgrim, to Man, may I say, today, 'Happy Birthday, and many happy returns'.

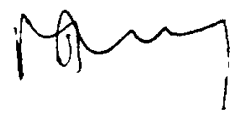

Marc MaURY

MORE than courage was needed to leave the academic enchantment of war-time Oxford for a Ministry of Pensions Hospital at Stoke Mandeville. But this is precisely what Ludwig Guttmann did in 1943 .

At that time the management of patients paralysed by spinal injuries was in a sorry state and with notable exceptions official thinking was slow to change. A minority of patients managed to live something approaching a normal life for a few years after injury. Many were a gens lucifugens-a people who shunned the light, hidden away by their relatives or incarcerated beyond hope in some institution.

Guttmann's plan was radical, if not revolutionary. His castigation of plaster beds was as unpopular among orthopaedic zealots as was his condemnation of early suprapubic cystotomy among urologists. His approach to the various Ministries was no 'cap in hand' affair but was mounted with skill and singular lack of compromise.

It would be difficult to epitomise his teaching, but the highlights are on performance more than pathology, and the development of the unparalysed muscles to the highest functional level. A visit to the International Stoke Mandeville Games amply demonstrates the success of this policy.

But this is history and is only one facet of a long campaign of clinical and administrative reform. The number of his succinct and convincing publications has not diminished over the years. They are essentially practical contributions, hallmarked by the precise neurophysiological observations expected of a master neurologist.

Like St. Paul he is afire with missionary zeal and from the Mother Church at Stoke Mandeville his epistles are studied in spinal injury units all over the worldmany of them direct or indirect foundations. He too, like the great Apostle, is an indefatigable traveller and in spinal units in this country and abroad we look forward to his electrifying visits for many years to come. The comparison could be extended further-not least in the Pauline virtue of 'caritas' or love for one's

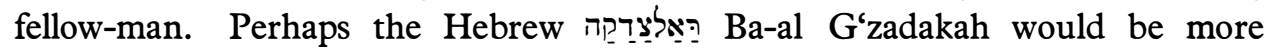
appropriate.

Sir Ludwig is a truly international man, oblivious of the artificial boundaries between nations, and wholly dedicated to the discipline which he has done so much to establish.

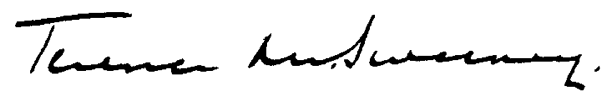

TERENCE McSweEney 
IN the summer of I960, at the Stoke Mandeville Hospital, was my first direct interview with Sir Ludwig Guttmann. I am one of the Japanese doctors who saw him many times and who has been taught by him. Having been under his care, and moved by his great humanity to rehabilitate the paraplegic as soon as possible, I, an inexperienced young man, made up my mind to use the best of my poor abilities for Japanese paraplegics.

Against much opposition I took part in the Stoke Mandeville Games in 1962 by leading the patients in my hospital and later in the Para-Olympics at Tokyo, and now have founded the Japan Sun Industries, a sheltered workshop. These ten years have passed only to solve the problems of paraplegia. I understand well how hard this is by direct experience and now I know the greatness of Sir Ludwig as a pioneer. I was so glad to see him well again though older at the Stoke Mandeville Games in Israel last year.

Under the stimulus of the Tokyo Games, Japan has surprisingly progressed in the field of rehabilitation, having previously lagged behind other countries. While staying at Aylesbury, I of ten heard that Sir Ludwig is the pope of paraplegics, but no one doubts that he is also the father of paraplegics not only in England and Japan but throughout the world.

I heartily congratulate him on his. seventieth birthday and wish him good health. Further I pray that he may play the leading part in this field for ever.

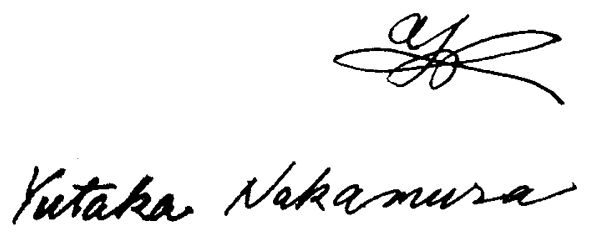

Y. NAKAMURA

THE seventieth anniversary of an illustrious man like Sir Ludwig Guttmann is a milestone in a fruitful prof essional career and for one like myself, who has been closely connected with him at Stoke Mandeville Hospital for a relatively short period, it is not easy to indicate all the major prof essional events of such a rich life. It might, however, be a measure of his greatness if I say that even the short period when I was with him, contained sufficient events to point out his greatness. I had the privilege to be present at the creation of the first International Stoke Mandeville Games, which were followed by many more and larger sports events. Every round in the wards, every talk during the breaks, and every discussion on the problems of spinal man, brought from his rich experience endless details which inspired all his pupils, stimulated their thoughts, and to the majority of them formed the basis of inspiration to carry on in the direction he had indicated. In my particular case I spent a comparatively short time at Stoke Mandeville Hospital in order to bring the lessons learned there to a new country, where that particular message was new at that time. Dr. Guttmann realised at once that the path that lay ahead of me in Israel would not be an easy one, and probably much more difficult than his was during his early days at Stoke Mandeville. Only later was I able to confirm how right his predictions had been. Each of his visits to Israel was an 
inspiration to all who met him and brought fresh hope to all paraplegics whom he examined. The wider circles in this country saw in him a magnetic personality, who could by the medium of his pupils inspire so many handicapped people to become pioneers in sport for the disabled in a new country. It must have been a great satisfaction for him when he saw the fruits of his efforts crowned by his nomination as President of the International Stoke Mandeville Games for the Paralysed, which took place in November I 968 in Israel. As one of his pupils, I would like to believe that this was an appropriate way to mark his seventieth anniversary.

Knowing how alert and energetic Sir Ludwig Guttmann is, I am confident that for many years to come he will continue his great work for the benefit of the disabled and for those who work in this field.

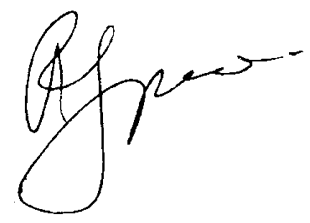

R. SPIRA

\section{SIR Ludwig GutTmanN, 'Congratulations'!!}

With great pleasure I received the letter about your seventieth birthday, but I was truly astonished at your 70 years, because you look so very young.

In Japan, the celebration of a seventieth birthday is called 'Celebration of rare longevity and is an occasion to congratulate one on long life'.

I would like to say again 'Congratulations', heartily, for your rare longevity, and in so saying I also mean that the admirableness of your achievement and your passion for work are rare. It is not too much to say that the progress in research, treatment and rehabilitation for paraplegic patients after World War II, throughout the world, of course including Japan, has been achieved by your effort and by that of your pupils.

Professor Tamikazu Amako, who is my teacher, is one of the leading men in this field in Japan. He sent Dr. Yutaka Nakamura to your hospital to learn about paraplegia, and he was also in favour of my study there. It shows how high the appreciation is in our country for your work. As you know, all the Japanese doctors who studied in your hospital, or visited it, have laboured well in the field of paraplegia, especially Dr. Yutaka Nakamura, who has done splendid work.

The events of Para-Olympic, I964, in Japan, impressed your name upon the minds of Emperor and people. And for myself, I will never forget your figure when you brought greetings in Japanese at the opening ceremony of Para-Olympic, and the friendly smiles of those attending.

Next, I would like to write about my several memories of your hospital. One day, as I had a cold, you bought a kerosene stove for me, considering my condition. I was pleased with your kindness for a foreigner who fell ill. I perceived the influence of your personality in the hospitality of your pupils and the staff of the hospital. For example, I was warmly welcomed at every part of the hospital during my stay. 
How many times I received invitations to their homes and enjoyed myself very much with their families. This hospitality gave me pleasure, but also gave me the courage to fight off homesickness and brought fruitful results to my study in the hospital.

May I say something about you ? Please look back to that day when we took dinner at the Nippon Club in London. They said that that day your bowels happened to be disturbed, but you tried many Japanese dishes-for example, Tenpura, Sashimi, Sukiyaki and so on-with Japanese Sake. The next day, you said to me, 'Dr. Tamai, I was surprised that Japanese Sake is a very good medicine for diarrhoea'. I had a great regard for you, because you respected my hospitality in spite of your condition.

I learned from you not only of paraplegia but also how important it is to persevere with enthusiasm for a long time to solve a difficult problem. I will always pray to God for your health and your continued activity in the field of paraplegia.

I would like to say again 'Sir Ludwig Guttmann, Congratulations'.

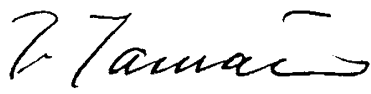

TAtSUji TAMaI

Sir Ludwig GutTmanN is 70. He has a lot to look back upon and a lot more to look forward to. Sir Ludwig does not need any introduction, nor do his achievements need enumerating. The Unit he has built from scratch has gained international repute and the International Stoke Mandeville Games have become a legend. His pioneering work has given thousands of patients a new interest and a new challenge.

He has devoted a quarter of a century to the interests of paraplegics and tetraplegics; not only giving them a new lease of life but also unfolding before us a part of medical science hitherto unexplored which carries with it extensive research possibilities. While I was at Stoke Mandeville Hospital, I made the common mistake of remarking that what is possible in Britain may not be possible in India due to the difference in economic conditions. But Sir Ludwig brushed aside what he considered to be an excuse for failure, with the remark, 'When I started at Stoke Mandeville Hospital, British economy was very low indeed'. Two years of inter-' esting work in India, watching my Paraplegic Unit taking shape, has convinced me that a sound basic training in this speciality and insight into the problems associated with it can do a great deal for paraplegics, whichever country they might be in.

On introducing intermittent catheterisation by the non-touch technique in the early management of the paralysed bladder, I have noticed a marked improvement in the sterility of urine, and, in the last two years, we have managed to discharge a number of paraplegics with sterile urine. This we owe to Sir Ludwig, who originally advocated this method of treatment in I949. I mention this specially because there is still considerable difference of opinion on this point amongst specialists all over the world.

Let me now relate a personal anecdote, which I remember with some pride and pleasure. My habit of asking for soft drinks at cocktail parties has always excited 
some good-humoured ridicule among my colleagues. Soon after I started working at Stoke Mandeville Hospital, Sir Ludwig said confidently that he would see that I started to take alcoholic drinks before I left his Department. Six years later, just before I left for India, seeing me with a glass of orange juice at a Christmas Party, he announced to the gathering, 'I admit utter failure in one respect, and that is to make Susie take alcohol'. I must say, I felt rather proud at having made Sir Ludwig, who believes that nothing is impossible, accept failure at my hands. One just should not have too much success.

As I mentioned earlier, there are tremendous possibilities for building, creating and exploring in the field of paraplegia, and the greatest tribute one can pay to Sir Ludwig is to create a Spinal Unit, one which Stoke Mandeville can be proud of. In fact, several countries have Stoke Mandeville trained doctors setting up such units, and if this continues, every part of the world will have a torch burning in his honour.

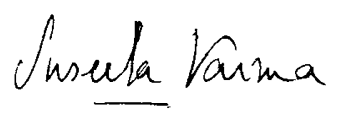

S. VARMA

WHEN on I February I944 Sir Ludwig Guttmann assumed responsibility of controlling and developing the Spinal Injuries Centre at Stoke Mandeville Hospital, a new era opened for the unfortunate victims of spinal cord lesions. Thanks to his pioneering work over the ensuing years, and despite many difficulties, Sir Ludwig succeeded in establishing a National Spinal Injuries Centre which was widely accepted as the leading world centre.

It must be a great satisfaction to him to visit the many centres which have been set up through his influence, and frequently by his ex-pupils, to the great benefit of disabled people all over the world.

The staff at the National Spinal Injuries Centre at Stoke Mandeville are proud and glad to work in the unit which bears the imprint of his personality and which we hope will continue to his satisfaction the work which he pioneered.

He has always expected his staff to work almost as hard as himself and we dare not wish him a happy retirement, but instead wish him many further years of useful work.

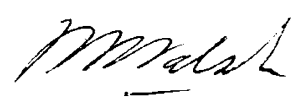

J. J. WALSH

THE publication of an entirely new journal is always an exciting adventure. When this is confined to a specialised subject in medicine, there are many factors to be considered carefully. The Editor must be a man of outstanding ability. His Editorial Board ought to have at least three outstanding characteristics-enthusiasm, vision, and loyalty. If these essentials are evident, then the publisher has a reasonable chance of success. 
When I was approached seven years ago to undertake publication of Paraplegia, The Official Journal of the International Medical Society of Paraplegia, by Sir Ludwig Guttmann and his colleagues, I felt honoured that my firm were being entrusted with this task. I do remember some of my misgivings: Would the quality of the articles command the attention of the specialists in most countries throughout the world? Would those interested in other specialities such as orthopaedics, neurology, genito-urinary work, neuro-surgery, etc., also be attracted to support our publication? The first few years suggest our aims have been achieved and we therefore salute the Editor, Sir Ludwig Guttmann of international fame, on his seventieth birthday.

This is the time when he ought to pause and consider-like many great men of past generations we feel sure he will be inspired to make his greatest contribution in his latter years. Might I refer our Editor to the Book of Psalms, which he must know and love so well, Number 92, 'The righteous will flourish as the palm tree. They shall still bring forth fruit in old age.' The Hindus reckon the palm tree has 360 uses, giving its shelter, succour, and refreshment to many weary travellers from the heat and burden of the day, but the greatest of all is that even in old age the best fruit is produced.

'Time that doth all things else impair

Still makes them flourish strong and fair.'

May Sir Ludwig's life follow this noble pattern.

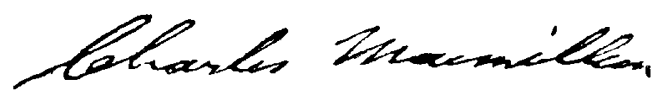

Charles Macmillan 